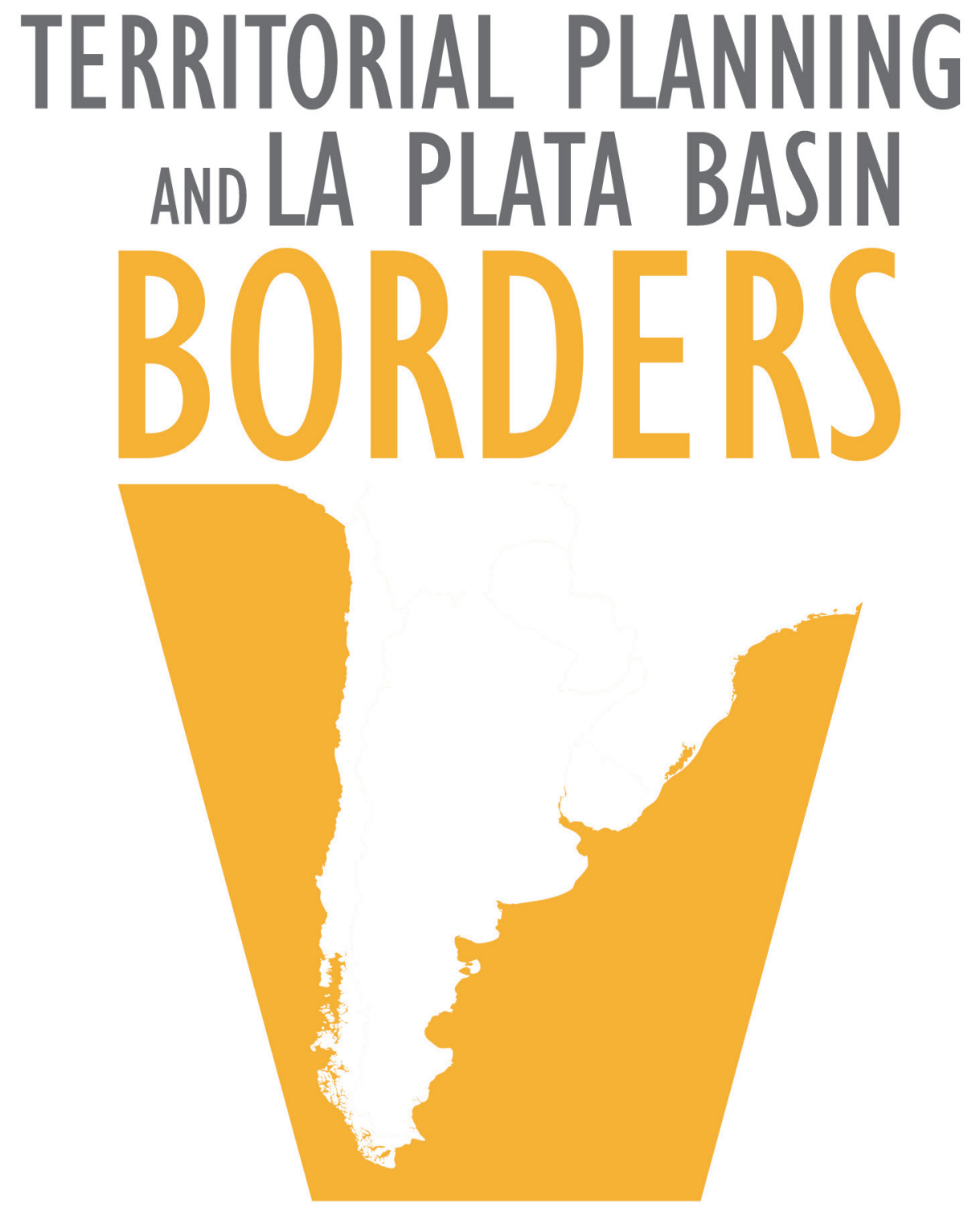

Antonio Paulo Cargnin

Aldomar Arnaldo Rückert Bruno de Oliveira Lemos

(Eds.) 


\section{Editors}

Antonio Paulo Cargnin

Aldomar Arnaldo Rückert

Bruno de Oliveira Lemos

\section{Editorial Board}

Carla Giane Soares da Cunha

Fernando Dreissig de Moraes

Irma Carina Macolmes

\section{Language Review}

Marlise Margô Henrich

\section{Layout}

Diego MeneghettI

Ronaldo Machado

\section{Cover Design}

Laurie Fofonka Cunha

\section{Institutional support}

Programa de Pós-Graduação em Geografia (POSGEA)

Instituto de Geociências (IGEO)

Universidade Federal do Rio Grande do Sul (UFRGS), Brazil

Secretaria de Planejamento, Governança e Gestão (SPGG)

Governo do Estado do Rio Grande do Sul, Brazil

\section{Dados Internacionais de Publicação}

Bibliotecária Regina de Carvalho Pereira CRB8/91772

\section{Letra1}

www.editoraletra1.com.br letra1@editoraletra1.com (+5551) 33729222 Rua Lopo Gonçalves, 554 Cidade Baixa 90050-350 Porto Alegre, RS, Brazil CNPJ I 2.062.268/000I-37
T327 Territorial planning and La Plata Basin borders / Antonio Paulo Cargnin, Aldomar Arnaldo Rückert, Bruno de Oliveira Lemos (Eds.) . - Porto Alegre : Editora Letra1, 2018. 232p.

ISBN 978-85-63800-35-0 DOI 10.21826/9788563800350

1. Brasil - Fronteiras.2. La Plata - Fronteira. 3. Território. I. Cargnin, Antonio Paulo. II. Rückert, Aldomar Arnaldo. III Lemos, Bruno de Oliveira. III. Título.

CDD 320.12 


\title{
IIRSA AND THE ROLE ASSIGNED TO THE LA PLATA BASIN REGION IN SOUTH AMERICAN PHYSICAL INTEGRATION
}

\author{
Eduarda Figueiredo Scheibe
}

\section{ABSTRACT}

At the end of 2000, in Brasilia, the twelve sovereign countries of South America launched a plan for the regional infrastructure integration that currently guides the actions of the South American Council of Infrastructure and Planning of UNASUR. The aim of the initiative is to connect these countries' transport, communications and energy networks across the subcontinent. The study of IIRSA Integration and Development Hubs, however, shows that there is a significant concentration of groups of projects in the cross-border region of $\mathrm{La}$ Plata Basin. Because to each IIRSA Hub and group of projects specific integration objectives and characteristicsare assigned, it is possible to infer from this overlap of proposals for territorial interventions with South American objectives that this cross-border region has a central role in the integration of the whole macroregion. In this sense, this article intends to analyze the type of physical integration promoted from the 2000s in the La Plata Basin by South American national governments, where the decision-making process related to IIRSA continues to be centralized. Furthermore, to the better understanding of the issues hereby presented, the historical background on the subregional physical integration initiatives will be also considered.

KEYWORDS Integration of the Regional Infrastructure of South America, physical integration strategy, the La Plata Basin. 
The initiative for IIRSA ${ }^{1}$ (Integración de la Infraestructura Regional Suramericana - Integration of the Regional Infrastructure of South America) as suggested by its name, presents a common strategy for the subcontinent's physical integration compiling projects in the transport, communications, and energy sectors within the area of influence of ten Integration and Development Hubs. Four of these Hubs overlap the La Plata Basin region.

The present study seeks to clarify the role of the mesoregion to the South American physical integration strategy. In order to answer this question, it explains some of the regional tools IIRSA provides to further understand the meaning of this concentration of projects in this part of South America. It analyzes the Hubs overlapping the La Plata Basin and its most immediate surroundings. Because the goal is also to identify any particularities to the mesoregion regarding the twelvestate plan, a comparative examination of all Hubs was conducted, and its results are hereby explored. This article also assesses the historical background on physical integration initiatives involving the La Plata Basin countries, especially as from the institutionalization of the La Plata Basin System, in 1969.

Despite the fact that some field works are briefly mentioned along the text, no comprehensive field work was conducted specifically to the objective of this study, the reason why the La Plata Basin region interests or strategies on regional development, those emanated from the mesoregion, are not subject to the following sections bellow. The IIRSA literature and the literature produced to analyze it from a critical point of view have been, nevertheless, largely explored a means to highlight the national and South American interests assigned to the region in case.

\section{IIRSA HUBS: THE INTEGRATION OF REGIONAL INFRASTRUCTURE IN SOUTH AMERICA}

By the end of the year 2000, representatives of the twelve sovereign countries of South America reunited in Brasilia agreed to launch a plan for integrating the regional infrastructure in the subcontinent. The plan, which would be known as

1 The acronym IIRSA is used in both Spanish and Portuguese languages. 
IIRSA, was certainly not the first to highlight the importance of physical connections for the achievement of regional integration goals. Previous commitments were made aiming to connect infrastructure networks in smaller regions or focusing in only one sector of infrastructure at a time. The innovation of IIRSA relies on proposing, on a South American scale, the connection of transport, energy and telecommunications networks, under the same initiative. Since 2010, IIRSA provides the guidelines to the South American Council of Infrastructure and Planning of UNASUR, the Union of South American States.

The most outstanding feature of the initiative, highlighted in the official documents as in the critical evaluations by academia and non-governmental organizations, is precisely IIRSA territorial planning strategy. The infrastructure projects are organized in Infrastructure and Development Hubs, while ech Hub represents, in practice, a section of South American territory and a specific dynamic of actual or potential integration, as specific objectives on physical integration are attributed particularly to each area of influence. This choice of territorial planning aims to increase the efficiency of investments made in infrastructure throughout the subcontinent, favoring the construction of connections between territorial nodes previously identified as economically dynamic.

In this sense, the IIRSA plan is not guided by, although it is not opposed to, the rationale of enabling new socioeconomic dynamics. It is, above all, designed to reduce the constraints on economic activities already underway and often playing a preponderant role in national economies. It is also in this sense that many of the critics over IIRSA point out that the architecture of Hubs prioritizes structures that contribute to maximizing development strategies based on extractive export economic activities (Carrion \& Paim, 2006; Ceceña, Aguilar \& Motto, 2007; Dijk, 2008; Svampa, 2011, among others).

The concept of integration and development Hubs had also been previously applied, but at national level. In Brazil, for example, similar Hubs had been proposed in 1996, within the scope of the government program Brasil em Ação. If, on one hand, these same Hubs were considered inefficient by scholars such as economist T. B. Araújo (2000), who considers them to be instruments that only increase inequalities between the different Brazilian regions; on the other hand, a study coordinated by E. Batista da Silva (1997), also from Brazil, which similarly used the notion of Hubs for Latin American integration, had a clear influence on the first version of the IIRSA plan (Inter-American Development Bank, 2000). 
Despite criticisms, according to the definition of documents published by IIRSA, the concept of Integration and Development Hubs goes beyond the one of transport corridors or of infrastructure networks. The IIRSA Hubs represent, in fact, the spaces articulated by these corridors and networks, "involving specific natural resources, human settlements, production areas and logistic services" (IIRSA, 2011, p. 8). The projects enrolled by IIRSA's portfolio are organized in ten Hubs and are aimed at assisting the development of their entire area of influence (see Figure 1).

As an aspect less explored by the literature about IIRSA, each Hub is further divided into groups of projects with smaller areas of influence and to which, as for the Hubs, specific goals are assigned. The purpose of this subdivision is to facilitate the negotiations and the planning of each project. This way, only the representatives of the countries and, sometimes, of the sub-national administrative units whose territories are most directly affected by the planned structures take part in the negotiations of each group of projects.

Case studies demonstrate that local authorities and interest groups' capacity for interference varies according to the type and location of the project ${ }^{2}$. In addition, the negotiations and decision-making process through which IIRSA materializes are largely centralized by national governments. Cross-border infrastructures are matters of competence for the representatives of so-called national interests, with selective preponderance over sub-national and sub-regional interests.

However, the map of IIRSA projects, an innovation of the initiative that is often underestimated in terms of its repercussions, allows the visualization and highlights the various scales of the integration process, in addition to the multinational one. Individual infrastructure projects - each stretch of road, each power transmission line or fiber optic cable connection - continue to be classified as national or binational projects, but are to be interpreted as part of a common South American physical connection strategy. The IIRSA portfolio of projects is recognized by all twelve States as indispensable for the success of regionalist goals in South America. At the same time, the planning of those as part of integration Hubs and smaller groups of projects draws attention to the fact that each bridge or stretch of road has parallel repercussions at other territorial levels.

\footnotetext{
2 The author has conducted interviews with local authorities in border areas between Brazil and Uruguay (in 2016) and Brazil and Peru (in 2017). Furthermore, other studies demonstrate the potential gap between local authorities along the Brazilian Borderland Strip and central-national authorities, such as those by A. R. da Silva (2011) and A. Rückert \& C. Carneiro Filho (2015).
} 
In addition, the spatial organization of IIRSA projects grants the possibility of capturing the different stages of connection and integration conditions observable in the various sub-regions of South America, since diagnoses were published and updated for each Hub of integration. The first few versions of those studies, which guided the definition of the priorities for each Hub from the initial years of IIRSA, were called "Business Visions". Currently these documents are named "Socioeconomic and environmental characterization". We can consider these publications as part of IIRSA's intangible dimension, together with the normative harmonization processes for the effective operation of the projected regional infrastructure networks.

The preparation of characterization studies is coordinated by the Institute for Integration of Latin America and the Caribbean of the Inter-American Development Bank (IDB), which hosts the Institutional Secretariat of IIRSA ${ }^{3}$. They report on the economic and social situation of each Hub's area of influence, as well as on their geographic characteristics and the main productive activities of those zones, with a clear focus on export-oriented activities, although they also intend to clarify the possibilities of intra-zone trade, in this case, intra-Hub trade.

It is important to notice that, because of the moment of its launch and the centralized of the decision-making process, at national level, it is possible to affirm that IIRSA had its continuity assured, and development conducted, mainly by national leaders who identified their government programs with leftist ideals. Regarding to the South American regional integration process, this translated into a discourse of priority approximation among South American countries in order to achieve greater autonomy of action on international affairs.

Notwithstanding, a brief review of the critical literature on IIRSA suggests that the plan would serve, to a large extent, the objectives of extra-regional international actors. Given that the period immediately preceding the launch of the initiative in 2000 was strongly marked by the discussions on the implementation of the Free Trade Area of the Americas, under the leadership of the United States, many of the initial analyzes interpreted the projected connections as intended to lay the material foundations precisely for the implementation of the neo-liberal contoured Pan-

\footnotetext{
3 The Institute for Integration of Latin America and the Caribbean (INTAL) is also responsible for compiling and coordinating researches on the development of common methodologies for the implementation of infrastructure projects, which cover topics such as environmental sustainability, logistics integration and territorial development from the point of view of local populations. Although the application of these methodologies is not mandatory, they represent an important advance in the subject of South American physical integration.
} 
American agreement - for instance, as seen in G. Carvalho (2003), M. C. Carrion and E. Paim (2006) and A. E. Ceceña, P. Aguilar and C. Motto, (2007).

These authors point out, unlike the most recent publications by the initiative itself, that the main objective of IIRSA would be related primarily to the exportation of South American products, mostly of commodities. The goals described for each of the integration Hubs and groups of projects do, in fact, highlight the export sectors as aimed toward overseas markets. As seen, the very organization of integration in Hubs is justified by the need to prioritize spaces in which there are cross-border dynamics that can attract financing for the construction of additional physical connections.

If, on one hand, this logic is based on the fact that foreign trade is an important part of the gross domestic product of all the countries that make up the South American bloc, on the other, it is possible to identify, through analysis of the same documents, a concentration of investments in infrastructure that benefit only few but large economic activities such as iron and copper ore mining industries, oil exploitation and soy cultivation (Scheibe $\&$ Rückert, 2014). More than that, the discourse of socioeconomic development as linked to the development of these same sectors often overshadows the objective of South American integration and autonomy itself, as it does for the sub-regions within the subcontinent ${ }^{4}$.

The following image (Figure 1) presents the ten Integration and Development Hubs of IIRSA. The next sections, however, make reference to only nine of these Hubs, as the Southern Andean Hub has, so far, no projects attributed to it. It continues to be portrayed on IIRSA maps, but there are no further documents on the subject. The image bellow also depicts the overlap of four Hubs around the La Plata Basin region area.

For the purposes of this work, 249 out of the 562 IIRSA projects were considered as located or immediately connected to the La Plata Basin region. As for the limits of the mesoregion, the area of influence of the ParaguayParaná Waterway Hub along with to the Atlantic coastal portion of the MERCOSUR-Chile Hub were established as reference. This decision was made based on the fact that, although there is no consensus over the exact limits of the La Plata Basin region, the river basin plays an important role to its identity, as does the polarization effect exerted by the Southeast region of Brazil.

\footnotetext{
4 This statement is particularly valid for the process of physical integration, because regionalism and regional relations in South America have developed on a broader basis than the commercial one since, at least, the beginning of the twenty-first century.
} 


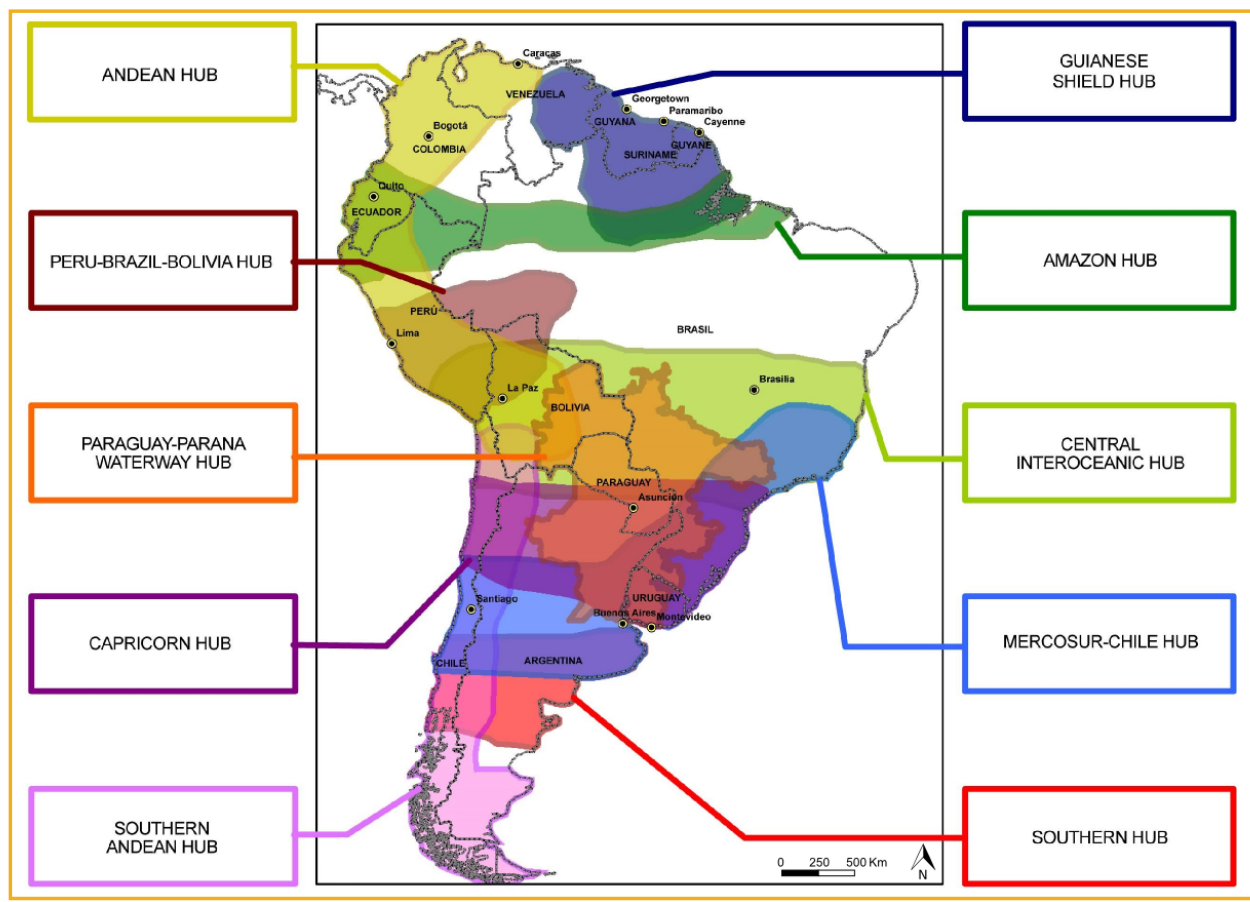

Figure I. IIRSA Integration and Development Hubs (IIRSA, 2011, p. 66)

\section{LA PLATA BASIN REGION AS THE AREA OF INFLUENCE OF EMERGING AND NON-EMERGING HUBS}

Certainly, analyzing the incidence of IIRSA in the La Plata Basin region is not limited to studying only the Hubs that pass through and overlap this particular region; not only because of the very nature of physical integration, its objectives and its architecture, which precisely predict the connection between the different mesoregions of the subcontinent. But above all, because, once the objective is to understand how IIRSA affects this region differently than it does to other parts of the subcontinent, it is essential that a comparative analysis be carried out between the overlapping Hubs in the La Plata Basin and those who do not cross this area.

The Project Portfolio for the year of 2009 informs the possibility of classifying the Integration and Development Hubs in two distinct groups. On one side 
there would be the two Hubs that have their identity more directly linked to the processes of regional integration Andean Community of Nations and Southern Common Market, the Andean and MERCOSUR-Chile Hubs, respectively. These two Hubs are characterized by "high concentrations of human settlements and clear patterns of regional trade and physical integration" (IIRSA, 2009, p. 15) and thus differentiated from the other Hubs, named the emerging Hubs. In the group of the emergent Hubs would be those characterized by the unfulfilled potential of integration due to "physical restrictions".

Even though the expression "physical restrictions" is no further explained, there are at least two possibilities for its interpretation. The first is related to characteristics linked to the physical constitution of the Hubs' area of influence, to those aspects that define the use of the territory to such a point that can impose barriers to certain forms of appropriation. The second concerns the efficiency of built structures for the appropriation of these areas while bearing in mind the purposes attributed to them, such as, restrictions to the particular goals of Hubs and development.

However, due to the overlap of two types of Hubs over the area that we understand here as the La Plata Basin region, the question of how should this region be analyzed regarding physical integration current strategy remains unanswered. In addition to a significant part of the MERCOSUR-Chile Hub, the ParaguayParaná Waterway Hub and parts of the Capricorn and Central Interoceanic Hubs coexist in this area. The latter three are identified as emerging Hubs as much as the Southern and the Guyanese Shield Hubs, for example.

Provided that the integration potential of a Hub is defined from the characteristics of the territory over which they exert their influence, what does the overlap of three emerging Hubs and the MERCOSUR-Chile Hub reveal about the role of the La Plata Basin for IIRSA strategy? At the same time, what characteristics of the La Plata Basin differentiate these four Hubs of integration from the other Hubs part of IIRSA?

In order to answer these questions, a two-phase study was carried out. Firstly, the documents of characterization of the area of influence and the integration objectives for each Hub were examined. This stage allowed for better understanding of the four Hubs with influence over the La Plata Basin region. Secondly, the data on the types of projects that constitute the nine IIRSA Hubs were reorganized in order to compare them according to variables selected from the outcomes of the first stage of analysis. The two steps are briefly described below. 


\section{CHARACTERIZATION OF IIRSA HUBS OVERLAPPING THE LA PLATA BASIN REGION ${ }^{5}$}

\section{PARAGUAY-PARANÁ WATERWAY HUB}

The Paraguay-Paraná Waterway Hub, not surprisingly, is the Hub whose area of influence corresponds in greater proportion to what we identify as the La Plata Basin region. All of the 84 IIRSA projects that it comprises are located within the region's territory. The main goal set for this Hub is to consolidate the waterway alternative for the cargo transportation from and among border countries. However, it is important to note that the notion of the La Plata Basin region exceeds the concept of hydrographic basin and also the one of waterway, so it would be a mistake to assume that this Hub represents more the situation of the region than the others listed here.

International borders here are mainly formed by the rivers of the La Plata basin, and thus constrain the international flow by land. Cross-border exchanges among these countries, therefore, depend on adequate infrastructure for the transposition of such constraints, such as bridges, which tend to concentrate the flow of land vehicles in a reduced number of spots. This Hub, however, focuses on the use of the waterways, while land transport structures for cross-border connection are contemplated by the other Hubs that overlap in this region.

Nevertheless, preventing overload of the land routes to optimize intra-regional trade is certainly not the only goal of the Waterway Hub. It is often emphasized in the description of its projects that the river system offers an important alternative for extra-regional outflow of Paraguayan and Bolivian products, for it would provide the two countries with access to the Atlantic Ocean, which is also true for some riverine zones of Argentina, Brazil and Uruguay. In addition, the affirmation of the Paraguay-Paraná Waterway as a South American interest favors the attraction of financing resources for improvements in ports and storage sites at its margins (Zugaib, 2006), an essential logistic condition for the further development of a

\footnotetext{
5 All data on numbers of IIRSA projects and their phase of completion mentioned in this section have been taken from the project listings on the information system for IIRSA portfolio as available on Aug. 25, 2017 (UNASUR, n.d.).

6 See historical background section for further discussion on this particular subject.
} 
diversity of economic activities, ranging from agricultural production to mineral extraction and advanced industrial activity (Koutoudjian, 2007).

As does A. Schweitzer (2000) when he describes the region studied by this work, this Hub also extends its limits incorporating the Tietê-Paraná Waterway, covered by group of projects number 2. For the Argentinian researcher, the city of São Paulo exerts a polarization effect over the La Plata Basin. The justification for this group of IIRSA projects is similar and highlights the relevance of the navigability conditions of the Tietê River so that it is possible to increase the flow of goods between the two fluvial systems. Soy and iron ore transportation were, from the earliest analysis, the central justification for this extension of the Hub (Koutoudjian, 2007, p. 554).

In addition to the transport sector, communications and energy sectors are covered by the Waterway Hub set of infrastructure projects. Regarding energy resources, the use of Argentine natural gas is on focus, in addition to improvements to the electrical interconnection network in the province of Corrientes. Also, in this respect, the complementarity of the energy projects of this and the other 3 Hubs analyzed below is very clear. Regarding communications, the main goal is to install a common system that makes navigation through Paraguay and Paraná Rivers possible 24 hours a day. Information coordination along the waterway is expected to make it more effective as part of a multimodal transport network.

\section{MERCOSUR-CHILE HUB}

The description by IIRSA documents and the architecture of the projected connections in this Hub's area of influence leads to the conclusion that the first goal of the MERCOSUR-Chile Hub is to provide access to Chilean ports for the four founding members of the Southern Common Market. Consequently, over $70 \%$ of the MERCOSUR-Chile projects are here considered as located in the region of the La Plata Basin, 82 out of 115.

Particularly noteworthy for the transport sector, the area of influence of this Hub can be considered as quite privileged in terms of pre-existing road connections: in a space that corresponds to just over $25 \%$ of the sum of the national territories of the 5 countries crossed by this Hub, $52 \%$ of the total road network of these same territories are concentrated. This is the opposite of what happens, for example, in the case of the Amazon Hub, where only $11 \%$ of the total road network of the Hub-participant countries serve its area of influence, which covers over $50 \%$ of the total territory of Brazil, Colombia, Ecuador and Peru together (IIRSA, 2011). 
The projects aimed at increasing railway transport, particularly, focus on bulk cargoes, which characterize a large part of this area's agricultural production. The growth of this sector of the economy is identified as the main source of pressure on the existing infrastructure (Ospina, 2007) and, therefore, the target of the improvements sought by IIRSA.

Moreover, it is significant that three of the six groups of projects in which this Hub is organized mention among their strategic goals to "make good use of scale and demand conditions in the area to attract public-private partnerships and disseminate the experience to other Hubs (Union of South American Nations, 2016, p. 209, 213 and 217) ${ }^{7}$. This aspect corroborates the idea that the Hub in question could be considered as a laboratory for IIRSA's physical integration policy (Scavini, 2011, p. 45).

The preset work shows, however, that we can also refer to the La Plata Basin region as IIRSA's laboratory: the mesoregion has the characteristics and has been the stage not only for physical integration policy experimenting, but also for regional integration in South America, in the broadest sense of the expression.

\section{CAPRICORN HUB}

The area of influence of the Capricorn Hub does not cover the entire La Plata Basin region, but it does cover an important part of it. In fact, all groups of projects in this Hub refer to the mesoregion directly or indirectly, either with projects physically located in the La Plata Basin, or with projects that aim to connect this region with the Atlantic and Pacific Oceans, especially with the harbor areas of Paranáguá, in Brazil, and Antofagasta, in Chile.

We consider, for the purpose of this study, that 54 of the current 77 projects of the Capricorn Hub are located or allow direct access to the La Plata Basin region - approximately $70 \%$. Though the concentration of investments is far more significant in the region, reaching $90 \%$, it is so largely due to the financing needs foreseen for one project: the duplication of an RN 34 section highway in Argentina, which is estimated to cost more than half of the total sum for all 77 projects.

\footnotetext{
7 The stated goal becomes even more relevant if we consider that attracting private investment in infrastructure in South America is one of the main objectives and one of which is farther from being reached by the regional initiative. Since its launch, only $20 \%$ of projects that had already been executed by the time of conclusion of this study had had private or public-private funding.
} 
Nevertheless, several projects listed by IIRSA project portfolio have an expected value for execution equal to zero, that is, to be determined in the future. This is only one of the evidences by which the variable amount of investments foreseen was not addressed in the present study regarding any of the Hubs ${ }^{8}$.

Once again, the transposition of geographical constraints characteristic to the international borders in this mesoregion is the challenge of the Hub, considering the rivers of the La Plata Basin in the eastern portion and the Andean Cordillera in the western portion. The territorial discontinuity reflecting the physical constitution of this area of influence becomes more apparent after the identification of four sub-regions that guide the strategy of IIRSA to this Hub (Sosa Pinilla, 2007). They are: the Atlantic Coastal Region, composed of the three Brazilian Southern Region states (namely Rio Grande do Sul, Santa Catarina and Paraná); the Northeast Region, composed of Argentinian Northeast, Eastern Paraguay and Mato Grosso do Sul in Brazil; the Northwest Region, which includes the Argentinian Northwest, the West region of Paraguay and the Bolivian portion under the Capricorn Hub area; and, finally, the Pacific Coastal Region, corresponding to the north of Chile. The Capricorn Hub is the only one of all IIRSA Hubs where sub-regions are mentioned and, among the objectives set forth by IIRSA projects, improvements in the internal infrastructure of these Hub's sub-regions are not the focus, but precisely the connection among them.

Regarding the energy sector, the three energy interconnection projects of the Capricorn Hub seek the improvement in power transmission capacity in areas where the existing infrastructure was assessed as overloaded. Complementing the projects of the same type in the Paraguay-Paraná Waterway Hub, these serve the north of Argentina and the eastern region of Paraguay.

The territorial discontinuity characteristic to the Capricorn Hub is reflected also in the diversity of exported products from its area of influence. Networks to export soy and wheat, however, are mentioned most frequently among the economy sectors that would be potential beneficiaries of the projects listed by

8 It should be noted that, as already verified in previously published studies (Scheibe, 2012), the amount of investments should not be considered as a variable for assessments of the IIRSA project portfolio, unless some particular issues are meticulously observed. There is, for instance, large variation in the values of the projects according to the type and conditions in which they are to be executed which has little relation with - or even necessarily related to - the purpose of the structure to be realized. Moreover, it is not unlikely to an amount of investment account only for the cost of viability studies. 
IIRSA portfolio. Unlike copper, exported to overseas markets from Chile, the two aforementioned agricultural products are grown and exported from regions located in the geometric center of the South American subcontinent, precisely in the La Plata Basin region.

\section{CENTRAL INTEROCEANIC HUB}

The Bolivian territory is crucial to the achievement of the main objective of this Hub: the horizontal crossing of the subcontinent from one coast to another. As the eastern and western sections of the Bolivian railway network are disconnected, the integration of the two parts certainly has the potential to contribute to this country's national integration, but the focus described in the project is mainly on reducing the export costs of the central section of South America to other regions of the globe.

The area of influence of Central Interoceanic Hub also crosses the Brazilian, Paraguayan, Chilean and Peruvian territories. Of the Hubs that cross the La Plata Basin, the Central Interoceanic has the lowest proportion of projects located in the region, approximately $46 \%$, but it is still relevant for our analysis.

The railroads are the focus of group of projects number 2 of this Hub, which, despite having all its projects located in Brazil, has the specific objective of increasing the participation of the railway network in the South American regional transport matrix, in addition to connecting Bolivia to Brazilian ports in the Southeast region of this country. In turn, group of projects number 1 highlights the works required for connecting Brazil and Chile across Bolivia and Paraguay, without the need for crossing Argentina, in order to guarantee and reduce transportation costs. It is clear, for the case of this Hub, the polarization exerted on the Basin by the Brazilian Southeast, as by regional nodes located in the northern regions of Chile?

Another important data for the proper characterization of the Interoceanic Hub is the concentration of GDP throughout its area of influence. It shows the inequality between the Brazilian portion and territorial units of the other countries. Brazil is home to $78 \%$ of the area's population and accounts for half of the Hub's territory. The Brazilian portion is, however, responsible for approximately $91 \%$ of Central

9 Improvements in Chilean and Peruvian ports are also among Central Interoceanic Hub projects, but evidently those were not considered as IIRSA projects within the region subject to this study. 
Interoceanic GDP (UNASUR, 2016a). This concentration of the production index suggests that the circulation of Brazilian products and the supply of this area are a central goal for this set of projects.

Equally relevant are the frequently mentioned potential of infrastructure projected on reducing the costs of activities related to the mining and the soy industry. The articulation between the Interoceanic and the Paraguay-Paraná Waterway Hubs builds an alternative for exporting the products of both economic activities and, at the same time, for the case of soy, enables the expansion of economically viable areas for its cultivation (Sosa Pinilla, 2008, p. 140).

However, groups of projects number 2 and 3 state specific goals aimed at producing effects on the La Plata Basin region for non-trade purposes. This is the case, for example, of the tourism-oriented conditions of access improvement to the Pantanal region. Even so, it should be noted that only one project, out of the twelve that make up these two groups, was effectively executed: the Pantanal Railroad. It was inaugurated in 2009, according to the project file in the IIRSA database (UNASUR, n.d.), but operated only until 2015 (Malagolini, 2016).

\section{THE LA PLATA BASIN HUBS COMPARED TO THE NON-LA PLATA BASIN HUBS}

As remarked, the exact perimeter of the La Plata Basin region is not a consensus. A. Schweitzer (2000), B. Azevedo (2009), R. Pérez Antón (2009), A. Rückert and C. Dietz (2013), for example, attribute in their studies, in some measure, different shapes to the region. Nevertheless, two aspects are often used to characterize it: the low population density in large tracts of land, in spite of the densely populated areas polarizing influence on them, and the strong presence of nature as a defining element of social interactions, especially the watercourses that cut through at the same time that they unite the territory.

As seen, these physical features of the territory are, according to the wording on IIRSA documentations, physical restrictions, which are attributed as characteristics of the emerging Hubs. However, it is easy to infer that physical restrictions do not equally affect the emergent Hubs that overlap in the geometric center of the subcontinent and those in the Amazon region, for example.

Furthermore, the La Plata Basin emerging Hubs also overlap the MERCOSURChile Hub, one of the two Hubs IIRSA it self highlights for their integrating potential 
and pre-existing infrastructure characteristics. In fact, in terms of infrastructure, even before IIRSA, the La Plata Basin region had already been characterized by its important stock of infrastructure, which makes it the most developed and varied in Latin America (Sánchez-Gijón, 1990, p. 111).

IIRSA literature mentions physical restrictions as key features in 8 out of the 10 Hubs of the initiative. And it's true that when large territorial portions of South America are observed, as extensive as the Hubs of IIRSA or as a mesoregion such as the La Plata Basin, hardly it will not be possible to identify some kind of physical constraint to the integration of its infrastructure. It is important, nonetheless, to differentiate this region from the others.

The table below shows the proportion of construction works that aim towards new infrastructure and those projects aiming at the improvement of existing infrastructure for each of the IIRSA Hubs. The use of this variable is justified as the conditions of the pre-existing infrastructure are among the most relevant aspects to tell emerging Hubs apart, as well as the Andean and MERCOSUR-Chile Hubs.

Those projects with any of the following specifications as for the type of work in the IIRSA database of projects (UNASUR, n.d.) were considered as new infrastructure: building of new power interconnections, building of new river ports, building of railways, transfer stations, carboelectric plants, infrastructure for installing border control centers, multimodal transportation, new airports, new sea ports, optic fiber, other energy infrastructures, paving (new work), railway by-pass, road by-pass and access to cities, thermoelectric plants. The following were analyzed on a case-bycase basis and classified as new infrastructure whenever appropriate: bridges (new ones and refitting), generation by means of nuclear power, hydroelectric plants (new ones and refitting), improvement of river navigability and tunnels (new ones and refitting).

Table 1 shows that within the same group of emerging Hubs there are the Guianese Shield and Peru-Brazil-Bolivia Hubs, which present approximately 80\% of projects that foresee the building of new infrastructure, as well as the ParaguayParaná Waterway Hub, with at least 55\% of the works aiming at refitting existing structures. In fact, the four Hubs on the La Plata Basin region are among the five with the smaller proportion of new works. This is reinforced if we observe only the set of projects that we consider to have a more direct incidence in the region specifically studied: only $45 \%$ of them are new works. Most of the projects for the 
region are aimed at improving the efficiency of an already established dynamics, one that overloads existing infrastructures.

\section{Table I}

Proportion of new works and works of improvement in each IIRSA Hub.

\begin{tabular}{lccccc}
\hline IIRSA Hubs & $\begin{array}{c}\text { Total of } \\
\text { projects }\end{array}$ & $\begin{array}{c}\text { New } \\
\text { works }\end{array}$ & $\begin{array}{c}\% \\
\text { new works }\end{array}$ & $\begin{array}{c}\text { Improvement } \\
\text { improvement }\end{array}$ \\
\hline MERCOSUR-Chile & 115 & 40 & $35 \%$ & 75 & $65 \%$ \\
Paraguay-Paraná Waterway & 84 & 37 & $44 \%$ & 47 & $56 \%$ \\
Capricorn & 77 & 40 & $52 \%$ & 37 & $48 \%$ \\
Amazon & 70 & 37 & $53 \%$ & 33 & $47 \%$ \\
Central Interoceanic & 63 & 34 & $54 \%$ & 29 & $46 \%$ \\
Southern & 45 & 25 & $56 \%$ & 20 & $44 \%$ \\
Andean & 65 & 39 & $60 \%$ & 26 & $40 \%$ \\
Peru-Brazil-Bolivia & 24 & 19 & $80 \%$ & 5 & $20 \%$ \\
Guianese Shield & 20 & 16 & $80 \%$ & 4 & $20 \%$ \\
\hline Total IIRSA & 562 & 287 & $51 \%$ & 275 & $49 \%$ \\
\hline
\end{tabular}

Table 2

Proportion of new works and works of improvement within the La Plata Basin region.

\begin{tabular}{lccccc}
\hline IIRSA Hubs & $\begin{array}{c}\text { Total of } \\
\text { projects }\end{array}$ & $\begin{array}{c}\text { New } \\
\text { works }\end{array}$ & $\begin{array}{c}\text { \% } \\
\text { new works }\end{array}$ & Improvement & $\begin{array}{c}\% \\
\text { improvement }\end{array}$ \\
\hline MERCOSUR-Chile & 82 & 30 & $37 \%$ & 52 & $63 \%$ \\
Paraguay-Paraná Waterway & 84 & 37 & $44 \%$ & 47 & $56 \%$ \\
Capricorn & 54 & 26 & $48 \%$ & 28 & $52 \%$ \\
Central Interoceanic & 29 & 19 & $66 \%$ & 10 & $34 \%$ \\
La Plata Basin region & 249 & 112 & $45 \%$ & 137 & $55 \%$ \\
\hline
\end{tabular}

It also should be noted that the same rivers that can be interpreted as physical restrictions, constitute, in practice, resources that justify part of the human settlements in the La Plata Basin, as well as alternatives for cargo and people transportation through the region. The rivers, seen as waterways, are alternatives of occupation and appropriation of space. On the contrary, for the two Hubs approaching $80 \%$ of new works, the physical features of territories corresponding to their areas of influence have always presented challenges for circulation and 
access infrastructure, which explain their low rates of compared human occupation, as seen on Table 3.

Table 3

Population density in each IIRSA Hub area of influence.

\begin{tabular}{lccc}
\hline IIRSA Hubs & Population & Area $\left.\mathbf{( K m}^{\mathbf{2}}\right)$ & People per Km $\mathbf{~}^{\mathbf{2}}$ \\
\hline MERCOSUR-Chile & $141,453,273$ & $3,216,623$ & 44.0 \\
Andean & $111,195,797$ & $2,845,658$ & 39.1 \\
Central Interoceanic & $100,150,302$ & $2,642,262$ & 37.9 \\
Paraguay-Paraná Waterway & $119,035,634$ & $4,036,541$ & 29.5 \\
Capricorn & $53,509,280$ & $2,722,534$ & 19.7 \\
Amazon & $132,687,257$ & $8,059,085$ & 16.5 \\
Peru-Brazil-Bolivia & $12,730,732$ & $1,159,504$ & 11 \\
Guianese Shield & $17,100,505$ & $1,603,643$ & 10.7 \\
Southern & $6,473,238$ & 686,527 & 9.4 \\
\hline
\end{tabular}

The data above indicate average population density as another useful characteristic to distinguish the emerging Hubs overlapping the La Plata Basin from other Hubs. The comparison in this case was made from data of the IIRSA Project Portfolio 2016 (UNASUR, 2016b).

Since spatial distribution of population is not homogeneous, the average population density of each Hub is useful to the extent that it reflects in what proportion the territorial units of greatest population density are included by the area of influence of those Hubs. In fact, the territorial occupation of South America has historically privileged the occupation of the coast, where a large part of the population is still concentrated, whereas the eight emerging Hubs according to IIRSA classification cover mostly the interior lands of the subcontinent. The La Plata Basin region, however, includes territorial nodes of great demographic concentration, as well as the La Plata Basin Hubs.

The emerging La Plata Basin Hubs, therefore, are distinguished from the other emerging Hubs because they present larger population settlements, although there are also territorial tracts of very low population density, and because of its overloaded infrastructure, which justifies the number of improvement projects proportionally to the number of new works. 
The difference, however, between the two sets of emerging Hubs should not be interpreted as merely evidence of the pre-existence of infrastructure and the expectations to its intensive use, which are used in order to justify the demands for their improvement. The difference between these two groups mainly reflects the fact that the so-called physical restrictions identified in the La Plata Basin region have posed less constraints to the development of the kind of infrastructure preferred by national and regional integration strategies up to the present. For this affirmation to become clearer, the next section provides a review on the historical background of regional and physical integration agreements concerning the La Plata Basin borders.

\section{THE LA PLATA BASIN SYSTEM AND THE (PHYSICAL) INTEGRATION OF THE LA PLATA BASIN REGION}

In 1969, also in the city of Brasilia, the La Plata Basin Treaty was signed by representatives of Argentina, Bolivia, Brazil, Paraguay and Uruguay. More than 30 years before the launch of the plan for South American physical integration, this agreement already highlighted the importance of integrating infrastructure in transport, communications and energy sectors to the regional integration process, but at mesoregional level (Tratado da Bacia do Prata, 1969).

However, as R. Pérez Antón states, the La Plata Basin region did not arise, in any relevant sense, with the Treaty of Brasília of 1969 (Pérez Antón, 2009, p. 79). The author emphasizes with this assertion that the notion of La Plata Basin region surpasses not only the geographical concept of hydrographic basin, but also goes beyond the aforementioned agreement among the five national States. It further stresses that the La Plata Basin region, although the category of region was not deliberately attributed to it, precedes the existence of these same States.

From colonial times, the region in discussion has played a significant role in the regional dynamics of what we now understand as South America. Portuguese and Spanish shared interests and competed for the potential of the main rivers and their tributaries as waterways. In addition to the routes for the traffic of goods, whether stated as legal or illegal, the first European explorers who circulated there were also interested in increasing their capacity of control over the interior lands of the new continent, made possible through navigation along these corridors. 
About this period, the analysis of R. Pérez Antón (2009) clarifies one characteristic common to all explorers: their lacking vision of the entire area. From very early it has been established a perception of the La Plata Basin region as a place for traffic. Control over the water path was a greater concern than the development of the lands surrounding it. Added to this is the fact that the end of the colonial period was marked by the creation of national States in which the administration is politically and geographically centralized, situation that leads to the concentration of the decision-making process on spatial planning and, often, a mismatch between the needs of the center and those of territorial units distant from these centers - in this case, a potential mismatch between local interests in the mesoregion, specially along international borders, and national interests.

Many researchers, such as A. Sánchez-Gijón (1990), E. Zugaib (2006) and A.-L. Amilhat Szary (2010), agree that the interaction among centralized States, such as regional agreements with integration goals, have been insofar insufficient for enabling an effectively regional administration of this cross-border territory. Although correct, the fact should not overshadow the perception and recognition, by these same States, of the existence of this territory as a distinct region. The succession of treaties and organizations that refer to the La Plata Basin region as such, although the limits of this area are unclear, is proof of this recognition: see the La Plata Basin System, institutionalized with the 1969 treaty, in addition to the Paraguay-Paraná Waterway intergovernmental committee and the multilateral development fund FONPLATA.

Even though the committee for the Waterway management, in operation since 1989, is part of the La Plata Basin System, the project for the waterway actually precedes the La Plata Basin Treaty of 1969. Proof of this is that the Paraguay-Paraná Waterway is cited as one of the priority instruments for the development of the La Plata Basin region. In addition, as suggested, the use of Paraguay, Paraná and Uruguay Rivers was already a cause of dispute during the colonial period, and some disagreements remained for decades after the signature of the Treaty in 1969. The conflict between the so-called national interests had great repercussions for this set of river routes, especially, as A. Sánchez-Gijón (1990) and E. Zugaib (2006) managed to elucidate, between the interests of Brazil and Argentina.

E. Zugaib (2006, p. 91) explains that this dispute of interests was reflected in the transverse versus longitudinal Hubs contradictions, giving rise to the policy 
of export corridors in the east-west direction, advised by Brazilian geopoliticians since at least the 1930s, although accentuated from the 1970s to the 1980s. The Brazilian strategy to overcome the lack of infrastructure within its territory in the $20^{\text {th }}$ century was conceived as to curb Argentinian influence over these areas, as this country would benefit from north-south connections, such as the Waterway.

The rapprochement of Argentina, Bolivia, Brazil, Paraguay and Uruguay for the coordination of regional initiatives regarding the La Plata Basin region has succeeded to raise the issue of improving the conditions of navigability and logistical infrastructure along the waterways. Only two decades later, though, the Intergovernmental Committee of the Paraguay-Paraná Waterway was created under the scope of the La Plata Basin System.

The period coincides with the growing Brazilian interest in promoting the products from the same areas that it previously tried to prevent from Argentinian influence. The expansion of the Brazilian agricultural frontier had boosted the population as well as the crops cultivation such as that of soy in this region. As a result, the viability for export of the La Plata Basin production was understood as directly dependent on the investment in reduction of transportation and storage costs. South American physical integration was thought so far, from the point of view of Brazilian foreign policy, as the connection between the two oceans, a logic that still plays a significant role to this day. However, from that time on, an opportunity was opened for the complementation of the bi-oceanic discourse with the discourse of internal connection to and through the La Plata Basin.

Nonetheless, there are different interpretations whether the Paraguay-Paraná Waterway is an advance or an estrangement from integration goals stated by the La Plata Basin Treaty of 1969. About the latter, R. Pérez Antón (2009) defines it as a sectoral policy of integrating inspiration on which is based an attempt at supranational management of this territory, although the treaty alone does not effectively establish supranational powers. However, he also affirms that other initiatives, anchored the regional appropriation of the rivers, such as the improvement of Paraguay-Paraná Waterway navigability, managed to dissipate these efforts.

P. Ligrone and L. Ménanteau (2009, p. 185), in turn, highlight the fact that the Paraguay-Paraná Waterway is a project aimed at the renewal of river transport mode at macroregional level. The authors emphasize that the project enhances the accessibility and add to the transportation capacity through the areas within the 
subcontinent, unlike what occurred during most of the $20^{\text {th }}$ century, marked by the growth and concentration of metropolitan areas on the Atlantic coast.

In effect, once the territorial development model focused on the coast, it encouraged priority development of coastal roads, subsidiary to maritime connections with other continents, prone to maintain some of the inherited relations from the colonial period. The Paraguay-Paraná Waterway, also known as Puerto Cáceres-Nueva Palmira project and listed by IIRSA, points out an alternative to diversify transport across the continent, while also undoubtedly increasing the access to remote areas in the subcontinent.

It is a fact that the Treaty signed in April 1969 states in its first article the intention of promoting balanced development and physical integration on the cross-border mesoregion, in order to ensure the common and sustainable use of natural resources. Although not specified, it is possible to interpret from the reading of the rest of the document that the notion of balanced development includes not only improvements in transport, energy and communications infrastructures, but also cooperation on economic, health, education and environmental issues. Therefore, aiming at broader objectives than the improvements concerning the waterway infrastructure.

In practice, despite the range of its goals, the initiatives directly associated with the La Plata Basin System, emphasize the theme of water resources use. The rapprochement between the States in this region, institutionalized by the Brasília Treaty, is, however, frequently cited, such as in the works of E. Zugaib (2006), B. Azevedo (2009) and P. Ligrone and L. Ménanteau (2009), as having a relevant role as a precursor to the integration process that would give rise to the Southern Common Market.

Other than that, as A.-L. Amilhat-Szary (2010) underlines, the case of the Fondo Financiero para el Desarrollo de la Cuenca del Plata (FONPLATA) is to be considered as well: a regional organization designed to fund regional integration also derived from the Treaty of $1969^{10}$. FONPLATA was constituted in 1974 and underwent an institutional reform in 2010 that equipped it to function as a

10 For the French researcher, the Brasilia agreement of the late 1960s is among the few examples of Latin American mesoregional strategies that aim for a territorial approximation, a dimension of integration processes often ignored by economic institutions. 
regional development bank. According to its annual reports from 2005 to $2016^{11}$, FONPLATA's operations revolve mostly on financing infrastructure projects, which include some listed by IIRSA portfolio, as well as other smaller budget projects in areas of international border or within the national territories of its five members.

In summary, although the La Plata Basin Treaty provided broader expectations in its text, improvements in terms of physical integration and the use of water resources were the priority issues for the creation of the regional intergovernmental system, implying that these would be the catalysts of integration and development. In this sense, the Paraguay-Paraná Waterway is in the genesis of the constitutive text of 1969 , as well as the emergence, two decades later, of an agreement specifically addressing this issue. The FONPLATA, in turn, is another example of the La Plata Basin System ramifications, as it is a regional instrument for financing projects that can contribute to the realization of the System's goals.

However, at the present, only the emphasis on the need for connection infrastructure remains. Moreover, the waterways certainly do not play the protagonist role on the mesoregion's development discourse. A role that, in terms of execution of projects, had ceased to exist much earlier.

At the end of the 1980s, A. Sánchez-Gijón had assessed the infrastructure situation in the transport, energy and telecommunications sectors in the La Plata Basin region. Since then, the author had identified the need for resumption of water and railways as an alternative to which was already considered an overloaded road network. A. Sánchez-Gijón (1990) concludes by unfolding the historical progress of infrastructural development in the region. According to his research, the level of integration of the transport systems is inversely proportional to the age of the subsystems involved (Sánchez-Gijón, 1990, p. 127), that is to say, the roads subsystem, more recent than the waterways, is far more integrated and developed than the river transport (and communication) subsystem, despite its importance to the colonial strategies of territorial appropriation. Along the same lines, he places the railroads as losing its importance notwithstanding the role they played to the consolidation of the Nation States in the $19^{\text {th }}$ century.

At this point, despite the contemporary intensification of the potential for infrastructural development, especially when compared to the technical limitations 
of the colonial period or even the political-economic limitations up until the mid-twentieth century, the researcher's conclusion remains valid nowadays. Although river and railway modalities are covered by the IIRSA plan, there is a clear preponderance of the road sector among the works in execution or already concluded after the launch of the initiative: currently there are 181 road, 30 river and 24 railway projects categorized in such phases. Similarly, among the projects of the four Hubs of IIRSA analyzed above, only $8 \%$ of the works in the transport sector belong to the railway sub-sector, and $14 \%$ to the fluvial one (UNASUR, n.d.).

It is possible, however, to identify that progress has been made since the $2000 \mathrm{~s}$ in energy interconnection matters: half of the 12 completed IIRSA energy projects for the La Plata Basin region refer to interconnection lines. The other six completed projects are for the power generation sub-sector and illustrate the diversity of sources used for power generation in the region, as they include three thermoelectric power plants, one nuclear power plant and two improvement works in the Yacyretá Binational Hydroelectric Plant. The Garabí and Corpus Christi hydroelectric plants, mentioned in the Sánchez-Gijón study and subject to binational agreements at least since 1980, are listed by IIRSA portfolio, but both are listed by IIRSA's database of projects as in the pre-execution phase (UNASUR, n.d.).

It is worth remembering at this point that IIRSA compiles existing projects proposed by one or more South American States and these projects are therefore elevated to the category of projects of regional interest. IIRSA, not unlike the La Plata Basin System at regionalism level, aims to coordinate at the same time as it is the result of intergovernmental negotiations. Both regional integration initiatives reflect the interests of its States Parties, and their capacity for implementation is limited to the actions taken by those States.

On this regard, attributing the reason to the completion of works after the year 2000 to the existence of IIRSA may lead to premature conclusions. In order to do so, it would be necessary to analyze each individual project to know the role of the initiative in carrying them out, since these projects had been considered priorities for years and many other conjuncture factors may have influenced their achievement. The IIRSA, however, represents a great advance in the ability to follow up all projects listed in its portfolio through a common regional tool and, precisely, to compare how the South American initiative can have different repercussions in the various sub-regions within the subcontinent. 


\section{FINAL CONSIDERATIONS AND CONCLUSIONS}

The IIRSA planning strategy can help to identify the sub-national repercussions of the integration process in South America. Even if IIRSA tends to prioritize territorial interventions associated with commodities trade, the integration Hubs and their subdivision into groups of projects, with smaller areas of influence, allow us to verify what interests are being assigned to these territories, although the motivations and resulting decision-making process of IIRSA are still centralized in the larger national centers. That is why we should emphasize the word assigned.

In this study, the La Plata Basin Hubs of IIRSA were analyzed, with emphasis on the groups of projects that are located in the region. This way it was possible to comprehend the role attributed to that region by the current physical integration plan, agreed among the independent States of South America. This assessment is of particular interest because the La Plata Basin region comprises large cross-border spaces, less populated and less equipped with infrastructure in transport, energy and communication sectors, while also comprising economic and political national centers. As a result, we could identify that the mesoregion reproduces the centerperiphery logic, also applicable to explain the extractive-export development model often attributed to the whole IIRSA as well as to other regional initiatives in South America.

The characterization documents of each IIRSA Hub, in regard to the population of their respective areas of influence, corroborate the idea of a region that is, in fact, quite populated when compared to other large spaces within South America. It is known, however, that this population rates reflect the great concentration of people in a small number of urban settlements in contrast to areas of low population density. In addition, it was found that this region, still in comparative terms within South America, is more developed in terms of infrastructure, playing a leading role for South American integration. Being at once under the influence of four out of the ten integration and development Hubs of IIRSA, the situation indicates the existing connections are far from enough to sustain the regional development and flows.

The study of the region through IIRSA documents is useful to understand to what extent the development interests for this region are contemplated by the initiative, although from the point of view of the national and centralized States of 
South America. But what would be the interests emanating from the mesoregion? The material hereby analyzed is not enough to accurately define these. It is possible, though, to reaffirm the recognition by the States about the need for cross-border regional treatment of development issues located at this particular region. In practice, IIRSA's multi-scale strategy makes possible to realize which are the central interests in this central-peripheral mesoregion. However, only from more detailed case studies would it be possible to identify the region interests as defined by regional territorial actors.

The physical integration strategy subject to this study is evidence, above all, to the selectivity of the national centers toward the demands of peripheral areas. Sub-national interests mentioned in the IIRSA projects are only implemented and enforceable insofar as they add up to the integration model privileged by national strategies, even when the latter is eventually inconsistent with integrationist discourses risen from those same centers. See, for example, the preponderance of roads to the detriment of railways and waterways for the transportation of goods, although these two last modalities had repeatedly been referred to as more efficient and cost-saving alternatives, even before the launch of IIRSA.

Nevertheless, the comparative approach to La Plata Basin and non-La Plata Basin Hubs clarifies what the overlap of three of the emerging IIRSA Hubs and the MERCOSUR-Chile Hub means to the mesoregion in case. The ParaguayParaná Waterway and Capricorn Hubs reveal complementary strategies, focused on the transposition of physical restrictions and the use of water resources, especially with the purpose of implementing multimodal transportation alternatives for the commerce of agricultural goods from the central area of South America.

The socioeconomic characterization of the Central Interoceanic Hub is equally relevant, for it demonstrates the income disparities within the La Plata Basin, with clear concentration in the Southeast region of Brazil. Also, the fact that the proportion of the Central Interoceanic new works projects located in the La Plata Basin region is greater (more than 65\%) than the ratio of the same kind of projects for the entire Hub (54\%) suggests that the Basin region area under its influence is precisely where the Hub lacks the most in connections. This situation reflects a weaker physical connection between Brazil and Bolivia than the one between Brazil and other countries in the Basin.

Regarding the MERCOSUR-Chile Hub, its main goal of connecting MERCOSUR's founding members to Chilean ports, in addition to a number of 
improvement projects in the conditions of Atlantic ports, suggest one more time a priority approach to the exportation of agricultural production from the La Plata Basin. The same roads, though aimed to the transportation of cargo, certainly have a relevant impact on the connectivity among the mesoregion cities and, therefore, their populations. The analysis of preexisting conditions of this Hub, the only one not classified as emerging by IIRSA, shows there is already an advanced regionalization of flows within the La Plata Basin region. Besides, given the privilege to the road network and the extremely low use of railways for the transportation of passengers, it, optimistically, suggests that this Hub is to positively affect the conditions for people circulation as well as for cargo.

Together, the goals of these four Hubs reinforce the central role that exportoriented crops productions, especially of soy, play in the development strategy designed by the national centers for the La Plata Basin region. All Hubs reference soy among the products to benefit from the physical connections, no other product being as much mentioned. There are, however, projects aiming for different objectives, such as power interconnection or touristic appropriation of part of the pre-existing railway network. Analyzed individually, however, the courses of these projects, even when carried out, reveal cases of existing structures not actually in operation.

Moreover, a fundamental result of this analysis is that the La Plata Basin region is also a legitimate IIRSA's laboratory. The status attributed to the MERCOSURChile is, in fact, partially due to the fact that this Hub has its area of influence mainly over the mesoregion. In addition, this Hub certainly is to IIRSA a space for carrying out pioneering studies and initiatives that can be used as an experiment for South American physical integration. Nevertheless, for the purpose of analyzing IIRSA's territorial repercussions, the La Plata Basin region and, consequently, the analysis of all four Hubs is substantially more accurate.

The variety of projects, the complementarity between Hubs, the preponderance of road transport modality in all Hubs, whether emerging or not, the contrast between more or less populous areas of influence and even the repeated mention of a reduced number of economic activities, in this case one single agricultural sector, all these aspects characterize the La Plata Basin region under IIRSA's influence.

Those interactions or assertions can only be accurately evaluated, though, through the analysis of a region or sub-region, other than one Hub. Even the strategies adopted by the Brazilian foreign policy toward the mesoregion are a starting point 
for understanding the role played by this country in the physical integration of South America. Consequently, it is possible to infer from these results that the $\mathrm{La}$ Plata Basin region regroups all of IIRSA integration and development expectations and strategy in a regionalist scale.

With that being said, it is of utmost importance to recognize that, at South American level, the La Plata Basin mesoregion actually comprises actually the components to be the center of the physical integration process and current regional plan. The preponderance of projects aiming for the improvement of already existing connections, the historical background here only briefly assessed and the relative proximity to the economic and political centers that polarize the mesoregion are some of the aspects that corroborate this hypothesis, which should be further explored with the replication of this study to other South American sub-regions.

\section{REFERENCES}

Amilhat Szary, A.-L. (2010). Frontières et intégration régionale em Amérique latine : sur la piste du chaînon manquant. In C. Flaesch-Mougin \& J. Lebullenger (Eds.). Regards croisés sur les intégrations régionales (pp. 307-341). Brussels: Bruylant.

Araújo, T. B. (2000). Dinâmica regional brasileira nos anos noventa: Rumo à desintegraçáo competitiva? In: CASTRO, I. E. ; MIRANDA, M. \& EGLER, C. (Eds.). Redescobrindo o Brasil: 500 anos depois (pp. 73-89). Rio de Janeiro: Bertrand Brasil.

Azevedo, B. (2009). Le Bassin du Río de la Plata dans la période coloniale : une histoire commune pleine d'actualité. In M. Guibert, S. C. Carrizo, P. Ligrone, B. Mallard, L. Ménanteau \& G. Uribe (Eds.), Le bassin du Río de la Plata: Développement local et intégration régionale (pp. 105-127). Toulouse: Presses Universitaires du Mirail.

Carrion, M. C. and Paim, E. (2006). IIRSA: Desvendando os interesses.Retrieved from: $<$ http://www.riosvivos.org.br/arquivos/iirsa_eli.pdfs

Carvallho, G. (2003). A estratégia da integração da infra-estrutura da América do Sul e o governo brasileiro. Retrieved from http://www.biodiversidadla.org

Ceceña, A. E., Aguilar, P. and Motto, C. (2007).Territorialidad de la dominación: La Integración de Infraestructura Regional Sudamericana (IIRSA). Buenos Aires: Observatorio Latinoamericano de Geopolítica.

Comunicado de Brasília. (2000). Retrieved from: <http://www.iirsa.org/admin_iirsa_web/ Uploads/Documents/comunicado_brasilia_esp.pdf > 
Dijk, P. (2008). Troublesome construction: the rationale and risks of IIRSA. European Review of Latin American and Caribbean Studies, 85, 101-120.

Fondo Financiero para el Desarrollo de la Cuenca del Plata. (n.d.). Reportes Anuales. Available from http://www.FONPLATA.org/comunicaciones/reportes-anuales.html

Initiative for the Integration of Regional Infrastructure in South America. (2009). Indicative territorial planning: Project Portfolio IIRSA 2009. Retrieved from: <http://www20. iadb.org/intal/catalogo/PE/2009/04494en.pdf>.

Initiative for the Integration of Regional Infrastructure in South America. (2011). IIRSA 10 years later: Achievements and challenges. Buenos Aires: BID-INTAL. Retrieved from http:// www.iirsa.org/admin_iirsa_web/Uploads/Documents/1b_iirsa_10_anios_sus_logros_y_ desafios_eng.pdf

Inter-American Development Bank. (2000). Un nuevo impulso a la integración de la infraestructura regional en América del Sur. Retrieved from: <https://publications.iadb.org/ handle/11319/3765? locale-attribute=en>.

Koutoudjian, A. (2007). Visión de negocios del Eje de la Hidrovia Paraguay-Paraná. Retrieved from: <http://www20.iadb.org/intal/catalogo/pe/2009/02858.pdf>.

Ligrone, P. and Ménanteau, L. (2009). Hídrovia, patrimoine fluvial et industrie du bois: le bas Uruguay(argentine, Uruguay) entre intégration transfrontalière et rupture. In M. Guibert, S. C. Carrizo, P. Ligrone, B. Mallard, L. Ménanteau \& G. Uribe (Eds.), Le bassin du Río de la Plata: Développement local et intégration régionale (pp. 77-103). Toulouse: Presses Universitaires du Mirail.

Malagolini, A. (2016, October 11). Do Trem do Pantanal, sobrou estação fantasma e o último funcionário. Campo Grande New. Retrieved from: <https://www.campograndenews. com.br/cidades/do-trem-do-pantanal-sobrou-estacao-fantasma-e-o-ultimo-funcionario $>$.

Ospina, G. (2007). Visión de negocios del Eje MERCOSUR-Chile. Retrieved from: <http:// www.iirsa.org/admin_iirsa_web/Uploads/Documents/mcd_vn_2007.pdf>.

Pérez Antón, R. (2009). Política, espacio e integración em la Cuenca del Río de la Plata. In M. Guibert, S. C. Carrizo, P. Ligrone, B. Mallard, L. Ménanteau \& G. Uribe (Eds.), Le bassin du Río de la Plata: Développement local et intégration régionale (pp. 77-103). Toulouse: Presses Universitaires du Mirail.

Rückert, A. and Carneirro Fillho, C.P. (2015). A gestão contemporânea das fronteiras do Brasil: defesa e separação x cooperação e integração. Anais do XVI Encontro Nacional da ANPUR. Belo Horizonte, MG: ANPUR.

Rüickert, A. and Dietz, C. (2013). Integração regional, a região transfronteiriça da bacia do Rio da Prata e os projetos de infraestruturas de conexão. Confins, 7. Retrieved from: <http:// confins.revues.org/8216>.

Sánchez-Gijón, A. (1990). La integración em la Cuenca del Plata. Madrid: Ediciones de Cultura hispánica. 
Scavini, A.S. (2011). L'Amérique du Sud, le nouveau paradignme brésilien de l'intégration régionale (Master's thesis). Université Paris 1 Panthéon Sorbonne, Paris.

Scheibe, E. (2012). Iniciativa para integração da infraestrura regional sul-americana (IIRSA): Consideraçôes preliminares sobre objetivos, atores e escalas de ação. Para Onde!?, 6, 01-06. Retrieved from: <http://seer.ufrgs.br/index.php/paraonde/article/view/35704>.

Scheibe, E. and Rüickert, A. (2014).A iniciativa para integração da infraestrutura regional sul-americana (IIRSA) como instrumento multiescalar de integraçáo. In A. Dorfman; C. I. Pacheco Sánchez; S. Y. Fernández Moreno. (Eds.). Planos geoestratégicos, migraçôes e deslocamentos forçados no continente americano (pp. 55-74). Porto Alegre: Letra1; IGEO/UFRGS.

Schweitzer, A. (2000). Aménagemenent du territoire et intégration régionale dans le MERCOSUR. Frontières, réseaux et dynamiques transfrontalières (Doctoral dissertation). Université de Paris III Sorbonne Nouvelle, Paris.

Silva, A. R. (2011). Perspectivas das politicas territoriais na Faixa de Fronteira internacional da Amazônia Oriental brasileira: Estados do Pará e do Amapá (Master's thesis). Universidade Federal do Pará, Belém.

Silva, E. B. (1997). Infra-estrutura para desenvolvimento sustentado e integração da América Latina. Rio de Janeiro: Expressão e Cultura.

Sosa Pinilla, P. M. (2007). Visión de negocios del Eje de Capricornio. Retrieved from: <http:// www20.iadb.org/intal/catalogo/PE/2008/01724.pdf>.

Sosa Pinillla, P. M. (2008). Visión de negocios del Eje Interoceánico Central. Retrieved from: <http://www20.iadb.org/intal/catalogo/PE/2008/01819.pdf>.

Svampa, M. (2011). Néo-"développementisme" extractiste, gouvernements et mouvements sociaux em Amerique latine. Problèmes d'Amérique latine, 81(3), 101-127.

Tratado da Bacia do Prata. (Apr. 23, 1969). Retrieved from: <https://www.dpc.mar.mil. $\mathrm{br} /$ sites/default/files/ssta/legislacao/hidrovia/trat_bcprata.pdf $>$.

Union of South American Nations. (n.d.). Information system project portfolio of COSIPLAN [South American Infrastructure and Planning Council]. Available from: <http://www.iirsa. org/proyectos/Principal.aspx>.

Union of South American Nations. (2016a).Caracterización socioeconómica y ambiental: Eje Interoceanico Central. Retrieved from: <http://www.iirsa.org/Document/Detail? Id=4298>.

Union of South American Nations.(2016b). Project portfolio 2016. South American Infrastructure and Planning Council. Retrieved from: <http://www.iirsa.org/Document/ Detail? Id $=4424>$.

Zugailb, E. (2006). A hidrovia Paraguai-Paraná e seu significado para a diplomacia sul-americana do Brasil.Brasília: Fundação Alexandre de Gusmão. 